\title{
Corporate taxation in Iceland and the international challenge
}

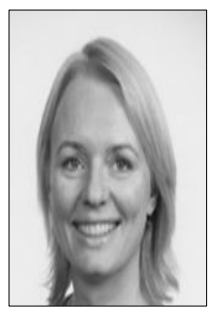

Economist Fjóla Agnarsdóttir Department of Taxation, Ministry of Finance and Economic Affairs

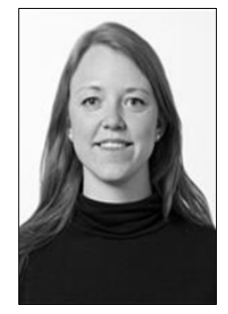

Legal Adviser Rakel Jensdóttir Ministry of Finance and Economic Affairs

Abstract: This article aims to describe the development in the field of corporate tax law in Iceland, from both legal and economic point of view, with a focus on measures taken to protect the tax base and in order to try to make Iceland an attractive place for investment and establishment companies. First, there will be a brief general description of the development of the corporate tax rate in Iceland since 2004 and an overview of new taxes that have been introduced for companies over the past ten years. Second, there will be an analysis of how the Icelandic legal framework provides for incentives for investment and establishment of companies in Iceland. Third, this discussion is to be followed by a section on the steps Iceland has taken in order to combat tax avoidance. Fourth, there is a general description of the economic development for the corporate taxation in Iceland since 1990 and fifth, there is brief discussion of the development of revenues from the corporate tax. Sixth, a short overview of the real investment in the Icelandic economy is given, and finally, the main conclusions of this article will be summed up with a short discussion on the main challenges Iceland is currently facing in the field of corporate taxation in today's globalised economy.

Keywords: Corporate taxation, Iceland, legal development, economic development, international challenge.

\section{Introduction}

In order to understand the development of the legislation in the field of corporate tax law in Iceland for the past decade the period should 
in fact be divided into two parts; namely before and after the collapse of the financial sector in October 2008. Before the financial crisis the tax policy in the field of corporate taxation was focused on creating attractive tax conditions for Icelandic and foreign companies in Iceland. Contrary to this, the emphasis of the Government's tax policy after the financial crisis in 2008 has been on increased revenues with higher tax rates, new taxes and increased efforts to protect the tax base i.e. with the introduction of new anti-avoidance measures.

A new center-right Government was formed in Iceland last spring but since 2009 there had been a center-left coalition in power in Iceland. According to the current Government's manifesto of 23 May 2013 the Government's intention is to analyse the tax system in Iceland in light of amendments that have been made for the past few years in order to come up with proposals for improvements with the aim to simplify the tax system, broaden the tax base and minimise tax avoidance.

The aim of this report is to describe the development that has taken place in the field of corporate tax law in Iceland, from both legal and economic point of view, with a focus on measures taken to protect the tax base and in order to try to make Iceland an attractive place for investment and establishment of companies, both domestic and foreign ones. First, there will be a brief general description of the development of the corporate tax rate in Iceland since 2004 and an overview of new taxes that have been introduced for companies over the past ten years. Second, there will be an analysis of how the Icelandic legal framework provides for incentives for investment and establishment of companies in Iceland. Third, this discussion is to be followed by a section on the steps Iceland has taken in order to combat tax avoidance. Fourth, there is a general description of the economic development for the corporate taxation in Iceland since 1990 and fifth, there is a brief discussion of the development of revenues from the corporate tax. Sixth, a short overview of the real investment in the Icelandic economy is given, and finally, the main conclusions of this article will be summed up with a short discussion on the main challenges Iceland is currently facing in the field of corporate taxation in today's globalised economy. 


\section{The Legal Part}

\section{The legal development of corporate taxation in Iceland and incentives for investment}

As mentioned above there has been a change in Iceland's tax policy after the financial crisis that hit Iceland hard in late 2008. This has been reflected in several new measures that have been adopted in order to further strengthen the revenue raising role of the tax system. Not only have the tax rates been raised, new taxes have also been introduced. This development will be discussed below in chapters 2.1 and 2.2.

\subsection{Tax rates}

The rate for corporate income tax has been $20 \%$ since 2011. Prior to that time the corporate income tax rate had been gradually decreased until 2008 with the goal to improve the competitiveness of Icelandic companies. The largest decrease was in 2001 when the tax rate dropped from $30 \%$ to $18 \%$. In 2007 , the rate decreased further, down to $15 \%$. As mentioned above there has been a change in Iceland's tax policy after the financial crisis in 2008. The corporate income tax rate was raised from $15 \%$ to $18 \%$ in 2010 and again in 2011 to $20 \%$. The partnership income tax rate has followed the same trend. That rate was also raised from $24 \%$ to $33 \%$ in 2010 and to $36 \%$ in 2011. This trend after the financial crisis has also been reflected in several new tax measures, as described below. ${ }^{1}$

\subsection{New taxes}

In addition to higher tax rates, new taxes have been introduced for certain economic sectors. In this context the financial sector had to bear a major burden with both the introduction of a special bank tax in $2010^{2}$ and a financial activities tax (FAT) in $2011 .^{3}$

The special bank tax is levied on commercial banks and credit institutions which have operating licences to receive deposits. Furthermore, from the income year 2014, financial undertakings which are currently in winding-up proceedings or receivership are also liable to the tax from the year 2014. The tax base is a taxpayer's total liability at the year-end. There is, however, a tax free limit of ISK 50 billion for each taxpayer. The tax rate is $0.376 \%$ for the year 2014 . Initially, the main

1 Further information on the development of the corporate and partnership tax rates is to be found in chapter 4.1.

2 Act No 155/2010 on Special Tax on Financial Institutions.

3 The Financial Activities Tax Act No 165/2011. 
economic objective of this special bank tax is to discourage excessive balance sheet expansion and thereby internalize some of the negative externalities associated with excessive financial sector debt accumulation and leverage. More recent objective of the tax is, at least partly, to be a financing measure to a newly introduced special household debt relief program in 2014-2017.

The FAT is paid by financial companies and insurance companies, who are generally exempt from the payment of VAT. The FAT has two main components. First, there is a levy of $5.5 \%$ on total wages paid by a company. The tax is levied on a monthly basis and is deductible expense against the corporate income tax base. Second, there is a special income tax of $6 \%$ on company's profit in excess of ISK 1 billion that is levied on an annual basis. ${ }^{4}$

In addition to the financial sector, the fisheries sector and the hydrocarbon industry have also been subject to new forms of taxation.

In the field of fisheries, Iceland has, for over three decades, maintained a system of Individual Transferable Quotas (ITQ) which gives holders the right to catch a certain part of Total Allowable Catches (TAC) during every fishing year. A new structure of fisheries fees was introduced in 2012 with a Fisheries Resource Rent Tax that has two components. First, there is a standard fee where the objective is to recover the administrative cost of running the system. Second, there is a special fee designed to capture the natural resource rent. ${ }^{5}$ Although recently introduced, the whole system of fisheries fees is already under revision by the government. The outcome of this revision may be a mixed system with fisheries fees and a special income tax that would come in addition to the payment of the general income tax at $20 \%$.

In 2008, new legislation on the taxation of the hydrocarbon industry was adopted, i.e. on oil and gas related activities. ${ }^{6}$ According to the new legislation, mainly based on the Norwegian model, the hydrocarbon industry will bear a higher tax burden than other industries. The new legislation applies to the taxation of all income derived from exploration, production and sales of hydrocarbons, including all derived activities such as transportation in pipelines or by ships. There are two components of this special tax scheme. First, all parties having received licences from the government for exploration and/or production of hydrocarbons, must pay a special $5 \%$ production levy

Article 71 para. 3 of the Icelandic Income Tax Act No 90/2003.

Act No 74/2012 on Fisheries Fees.

Act No 170/2008 on the Taxation of Hydrocarbon Production. The Act has now been replaced with Act No 109/2011 on the Taxation of Hydrocarbon Production. 
that is calculated from the value of the quantity of hydrocarbons, counted in barrels. Second, all taxable entities under the new legislation are subject to a special hydrocarbon tax on their income in addition to the general corporate income tax. The tax rate of the special hydrocarbon tax is progressive and decided as a part of the profit rate and the ratio is 0.45 . When calculating the tax base for this tax, special rules apply as regards deductible financial costs and other deductible expenses that deviate from the general rules for corporate income tax as outlined in the Icelandic Income Tax Act. This legislation has been ineffective as no oil or gas wells have been found so far within Iceland's territorial grounds.

The primary aim of those new taxes has been to collect higher revenues due to the poor situation of the public finances after the financial crisis. However, other objectives have also been present. In case of the banks, for instance, the objective underlying higher tax burden has not only been to raise revenues for the state because of the extensive cost leading from the collapse of the Icelandic banks but also to ensure financial stability and reduce risk seeking behaviour of financial institutions. As regards the fishing industry and hydrocarbon production industry, the aim of increased taxation in the sectors has partially been to ensure that the Icelandic nation as such will benefit from the use of common national resources.

\subsection{Tax incentives for foreign investment}

At the same time, when the Icelandic Government has been increasing the tax burden for companies in Iceland, some steps have also been taken in order to revive investment and the establishment of companies in Iceland. This has mainly been conducted with some sector specific tax incentives. In the field of taxation, a new legislation was passed in 2010 where incentives were granted for domestic as well as foreign companies that were planning to invest in Iceland with Act No 99/2010 on Incentives for Initial Investment in Iceland ("the Investment Act"). ${ }^{7}$ According to the Act companies, investing directly in Iceland could apply to the Ministry of Industries and Innovation for certain tax concessions, e.g. fixed income tax rates, exemption from industrial charges, permission for accelerated depreciation of assets and lower social security contributions on wages. This investment scheme was only applicable until 31 December 2013 and seven companies have already concluded special investment agreements based on the scheme. Since the Investment Act has now expired, any specific tax incentives for individual companies need to be negotiated on a ca- 
se by case basis with the adoption of a special legislation for each company.

Some tax incentives were adopted in order to support innovation and development in 2010. ${ }^{8}$ According to this scheme companies that are engaged in R\&D projects confirmed by the Icelandic Centre for Research may deduct $20 \%$ of the costs of these projects from their income tax due. The total costs for calculation of the deduction may not exceed ISK 100 million (150 million in specific cases) in a tax year. The legislation is applicable until 31 December $2014 .{ }^{9}$ The aim of those tax incentives is mainly to support $R \& D$ projects for domestic companies although foreign companies may also benefit from them.

In 2008, Iceland adopted certain tax incentives with a new tax scheme for merchant vessels with the establishment of an Icelandic International Ship Register (IIS). ${ }^{10}$ The main aim was to create incentives for merchant vessels to register in Iceland, but at this time no such vessels were registered in Iceland. The tax scheme provided that, instead of the ordinary corporate tax rate on profits, shipping companies could avail themselves of a more favourable tonnage tax, allowing shipping companies to calculate their profits on the basis of a notional profit per day depending on the tonnage of the ship concerned. To qualify for the tonnage tax, companies would have to register in the IIS. This new tax scheme was not a success since no companies registered in IIS. Furthermore, the EFTA Surveillance Authority considered the scheme to be in breach of the State Aid rules of the EEA Agreement. ${ }^{11}$ The tax scheme as set out in Act No 86/2007 on the Taxation of Merchant Vessel Operations was repealed in 2011. Now there are plans to start a revision of the tax rules for merchant vessels in Iceland again. The aim of that work would be to assess whether it is possible to create feasible tax conditions in Iceland in order to have more merchant vessels registered in Iceland.

The above mentioned legislative acts are isolated examples of tax measures taken in order to create incentives and attractive investment conditions i.a. for foreign companies in Iceland. However, for the time being it is difficult to attract foreign investment in Iceland and the domestic tax rules do not play the main role in that context. Since the collapse of the banking system in autumn 2008, Iceland has been applying capital controls on cross-border movements of capital. Such controls do not, in general, make Iceland a feasible place for foreign investment at the moment. However, there is a program in force on

8 Act No 152/2009 on Support for Innovation Enterprises.

9 A discussion on the effects of the R\&D tax incentives is found in Chapter 4.6.

10 Act No $86 / 2007$ on the Taxation of merchant vessel operations.

11 EFTA Surveillance Authority Decision No 303/09/COL of 8 July 2009. 
"new investment" where some incentives are granted to new investors via currency concessions held on a regular basis by the Icelandic Central Bank. ${ }^{12}$ Although capital controls are to be seen as a major deviation from the rules on the free movement of capital, as laid down in Article 40 of the Agreement on the European Economic Area ("the EEA Agreement $\left.{ }^{\prime \prime}\right)^{13}$ the EFTA Court has given its consent of the rules, at least temporarily in light of the economic situation in Iceland. This is, however, subject to revision when time goes by if the conditions for applying the controls will not continue to apply in the future. ${ }^{14}$

Finally, it is worth mentioning that double tax agreements (DTAs) are an important factor when companies are considering setting up businesses and investing in other countries. Iceland does not have an extensive treaty network of DTAs but the situation has been improving for the past few years. Iceland has concluded DTAs with 44 countries, thereof 5 are waiting for ratification. Those agreements are mainly based on the credit method although there are some examples of the application of the exemption method. If there is no agreement in place between countries tax relief may be granted by way of an ordinary tax credit against national income tax at the discretion of the Icelandic Tax Authorities.

\section{Base erosion and profit shifting}

For the last few years, some major legislative steps have been taken in order to combat tax avoidance in Iceland. Until 2009 there was only a general anti avoidance principle in the Icelandic Income Tax Act which had been interpreted by the Supreme Court to the effect that a transaction may be disregarded if its purpose is only to circumvent tax legislation. ${ }^{15}$ Iceland introduced CFC-rules in 2009 and special transfer pricing rules in late 2013. Furthermore, some work has been ongoing concerning thin capitalisation and exit taxation. It is also worth mentioning that Iceland has been strengthening its network of international agreements on administrative assistance in the exchange of information.

Below is a short overview of the main development for the past few years in this field.

12 See Article 13 litra m) in the Foreign Exchange Act No 97/1992, with later amendments.

13 Iceland has notified to the protective measures on capital movements to the EEA Joint Committee in accordance with Article 45 of the EEA Agreement.

14 See Case E-3/11 Pálmi Sigmarsson [2011] EFTA Court Reports, p. 430.

15 Article 57 Paragraphs 1 and 2 of the Icelandic Income Tax Act No 90/2003. 


\subsection{CFC-rules}

CFC-rules were adopted in 2009, but prior to that time no such rules were applicable in Iceland. According to the rules, if a non-resident company in a low-tax jurisdiction is owned or controlled (directly or indirectly), by resident taxpayers (corporate or individual) its profits are attributed proportionately to its resident shareholders and taxed according to the Icelandic income tax rate. This is the case regardless of whether the profits have been distributed or not.

According to the Icelandic CFC-rules the term "low tax jurisdiction" is defined as a country where the general income tax rate on corporate profits is less than two thirds of the Icelandic rate that would apply if the company was resident in Iceland.

The CFC-rules are not applicable if one of the following conditions are met. First, if the company is resident in a treaty country (outside the EEA, Switzerland and the Faroe Islands) and its income is not mainly financial income. Second, if the company is resident in an EEA State, Switzerland or the Faroe Islands and engaged in genuine business activities in that country and the Icelandic tax authorities can request all necessary information according to an international treaty.

The objective of adopting CFC-rules in Iceland was to combat tax avoidance, mainly due to the global development where movements of capital have been liberalised extensively for the past years. However, as explained above, capital movements are heavily restricted in Iceland for the time being and therefore the new CFC-rules have not been applied much in practice.

\subsection{Transfer pricing}

Statutory rules on transfer pricing entered into force at the end of $2013^{16}$ but until that time no specific rules on transfer pricing with a general applicability were applicable in Iceland apart from the general anti avoidance principle mentioned above. However, there were some statutory rules on transfer pricing in specialised tax legislation such as the Act No 109/2011 on hydrocarbon production. ${ }^{17}$

The new transfer pricing rules in the Income Tax Act apply both to domestic and international transactions. There is an explicit reference to the OECD Transfer Pricing Guidelines for Multinational Enterprises and Tax Administrations in the Icelandic rules and the intention is to take notice of the OECD work in this field when applying the Icelandic rules. Not all parties are subject to a documentation obligation since the obligation applies only to companies/entities where the an-

16 Article 57 para. 3-6 of the Income Tax Act No 90/2003.

17 See e.g. Article 9 paragraph 3 in Act No 109/2011 on the Taxation of Hydrocarbon Production. 
nual turnover exceeds 1 billion ISK or if the total assets are above that amount. According to the Icelandic rules it is not possible to have an advance price agreement (APA) from the Icelandic tax authorities.

For the time being, special rules on some technical and procedural aspects of the new transfer pricing rules concerning issues such as transfer pricing methods and the documentation obligation are being drafted.

\subsection{Thin capitalisation}

There are no statutory thin capitalisation rules in force in Iceland apart from the general anti avoidance principle mentioned above. However, there has been some ongoing work in this field since 2011, when the Minister of Finance and Economic Affairs appointed a working group on thin capitalisation. The working group submitted a report on the issue in June 2012, with suggestions on how to formulate new thin capitalisation rules.

Although there are no general rules on thin capitalisation in Iceland such rules can be found in Act No 109/2011 on the Taxation of Hydrocarbon Production. According to Article 10 paragraph 2 of that Act it is stated that when the hydrocarbon tax is determined, financial costs deducted from the year's income may not exceed $5 \%$ of the liability position, including receivables and inventory, at the end of the relevant financial year.

\subsection{Exit taxation}

The issue of exit taxation has been on the agenda in Iceland for the past few years and the focus has been on the exit taxation of companies that are merging cross-border.

The rules on the taxation of cross-border mergers were amended in 2013 but before that time domestic mergers could benefit from a tax exemption while cross-border mergers were subject to exit taxation at the time of relocation of the merging company. ${ }^{18}$

The EFTA Surveillance Authority considered the Icelandic rules on mergers to be in breach of the principles of freedom of establishment and free movement of capital as laid down in Articles 31 and 40 of the EEA Agreement and started infringement proceedings against Iceland in 2012 that ended with a ruling from the EFTA Court in December 2013. In its ruling of 2 December 2013 the EFTA Court came to the same conclusion as the EFTA Surveillance Authority, i.e. that the discriminatory treatment of domestic and cross-border mergers was

18 This was the conclusion of a binding opinion No 1/08 of 4 February 2008 from the Directorate of Internal Revenue (embætti ríkisskattstjóra). 
in breach of the provisions in the EEA Agreement on freedom of establishment and the free movement of capital. ${ }^{19}$

Iceland has now amended its legislation as regards the taxation of cross-border mergers. The new rules, applicable as of 1 January 2014, imply that companies that intend to merge cross-border (within the EEA) can choose between two options. Either they can pay tax on unrealised capital gains relating to assets and shares that accrued while the company was established in Iceland or they can decide to postpone the payment of the tax. A deferral of the payment of the tax can only be granted for up to five years irrespective of whether the assets have been realised or not at that time. ${ }^{20}$

\subsection{Administrative assistance in the exchange of information}

For the past few years Iceland has concluded several agreements on administrative assistance in the exchange of information. In this context, Iceland, as a very small state, has enjoyed the benefit of Nordic co-operation. In 2006, joint Nordic co-operation under the auspices of the Nordic Council of Ministers began to co-operate the Nordic approach for entering into information exchange agreements with tax havens. This has mainly been done in order to strengthen the Nordic negotiation position in relation to tax havens and to keep costs for the negotiation work down. A steering group made up with representatives from all the Nordic countries co-ordinates the negotiation efforts. The aim of this project was to follow up on OECD's work to combat international tax evasion. Presently, Iceland has an extensive exchange of information network covering almost 100 exchanges of information partners. According to a peer review report from the Global Forum on Transparency and Exchange of Information for Tax Purposes, from 2013, Iceland got a very good rating for its overall performance in this field. $^{21}$

\subsection{Advance Rulings}

Both resident and non-resident companies may request advance rulings on most aspects of corporate income taxation from the Directorate of Internal Revenue. A ruling can only be obtained on tax consequences of a future transaction and is only issued if it is of substantial importance. The advance rulings are valid without time limit. There is an ongoing discussion of the need to revise the advance ru-

See Case E-14/13 The EFTA Surveillance Authority v Iceland, not yet reported.

20 See Articles 51 and 54 of the Income Tax Act No 90/2003.

21 http://www.eoi-tax.org/jurisdictions/IS\#latest 
ling legislation that has remained almost unchanged since its implementation in $1999 .^{22}$

\section{The Economic Part}

\section{The economic development of corporate taxation in Ice- land}

The taxation of corporate profits in Iceland is a classical system and generally in accordance with the systems that are found in other European countries. Companies are resident for tax purposes if they are registered with the Enterprise Registry of Iceland or if the place of their effective management is in Iceland. After the financial crisis in 2008, the Icelandic Government requested the International Monetary Fund (IMF) to conduct a review of the tax system. The outcome of the review was published in two reports, in June 2010 and May 2011. ${ }^{23}$ According to the reports, the Icelandic corporate tax system seems to be an efficient one that does not require major changes. However, some specific shortcomings of the system were emphasized in the reports that should be dealt with in near future, such as the treatment of holding gains and losses, debt forgiveness, complex financial operations, and excessive leverage. Also issues related to closely held corporations and incorporated self-employed workers, as well as to the CIT rate and its interaction with the PIT. The Icelandic Government has already tackled some of the issues mentioned in the IMF's reports, but most of them are still under consideration.

\subsection{The development of the corporate income tax rates}

The figure 1 shows corporate and partnership income tax rate schedule from 1990 to 2014. It shows clearly, that there has been a large change in both corporate and partnership income tax rate since 1990. The largest decrease was in 2001 when the tax rate dropped from 30\% to $18 \%$. In short, the corporate income tax rate gradually decreased until 2008, in some instances with broadening of the tax base, with the goal to improve the competitiveness of Icelandic companies and to attract foreign investment.

As mentioned above there has been a change in Iceland's tax policy after the financial crisis that hit Iceland hard in late 2008. This has

22 Act No 91/1998 on Advance Rulings.

23 Improving the Equity and Revenue Productivity of the Icelandic Tax System; IMF, June 2010 and Advancing Tax Reform and the Taxation of Natural Resources; IMF, May 2011. 
been reflected in several new measures that have been adopted in order to ensure the collection of tax revenues. The corporate income tax rate was raised from $15 \%$ to $18 \%$ in 2010 and again in 2011 to $20 \%$. The partnership income tax rate was also raised from $24 \%$ to $33 \%$ in 2010 and to $36 \%$ in 2011.

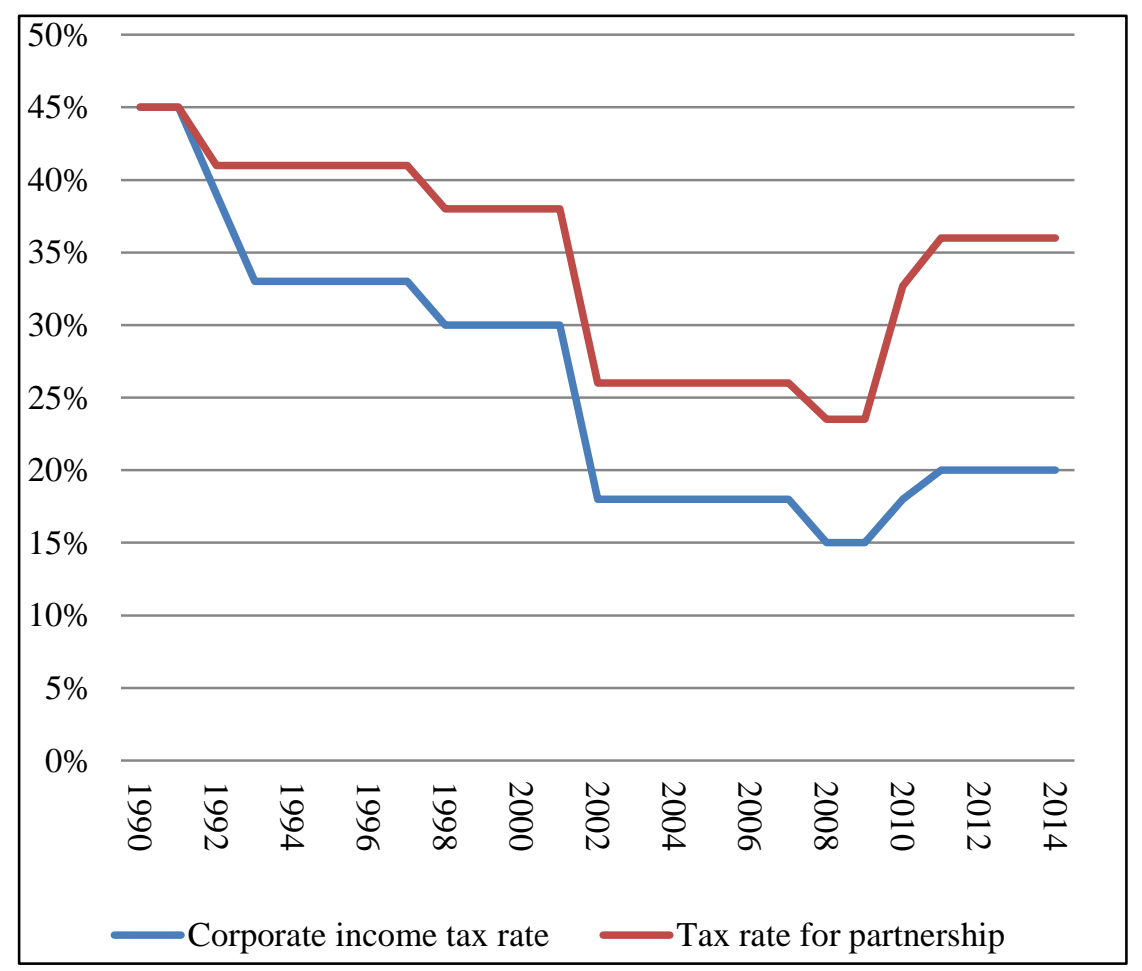

Figure 1. Corporate and partnership income tax rate

Source: Directorate of internal revenue.

\subsection{The development of the capital income tax rates}

Capital income tax was first implemented in 1997 with a broad tax base with $10 \%$ tax on all capital income. Before that interest income were not taxed at all, while dividends were taxed as ordinary income above a certain threshold. The capital income tax was raised to $15 \%$ in 2009 and finally to $20 \%$ in 2010 , as a part of the government plan to raise tax revenue. To offset the rise in the capital income tax the tax base was tightened. The tax exemption limit for individuals' interest income where raised to ISK 100,000 and for the income year 2014 it's raised to ISK 125,000 . The tax base on rental income is $70 \%$ of total rental income.

According to the IMF, one of the problems with the dual income tax in Iceland (capital income being taxed separately from other inco-

160 Fjóla Agnarsdóttir \& Rakel Jensdóttir 
me of individuals) is misallocation of labour and capital income within closely held companies. ${ }^{24}$ For 2014 the corporate income tax is $20 \%$, capital income tax $20 \%$ and partnership rate $36 \%(=0.20+(1-$ $0.20)^{*} 0.20$ ). The favourable tax regime for corporate profits and partnership income relative to labour income has created incentives to move from self-employed over to private limited and partnership companies.

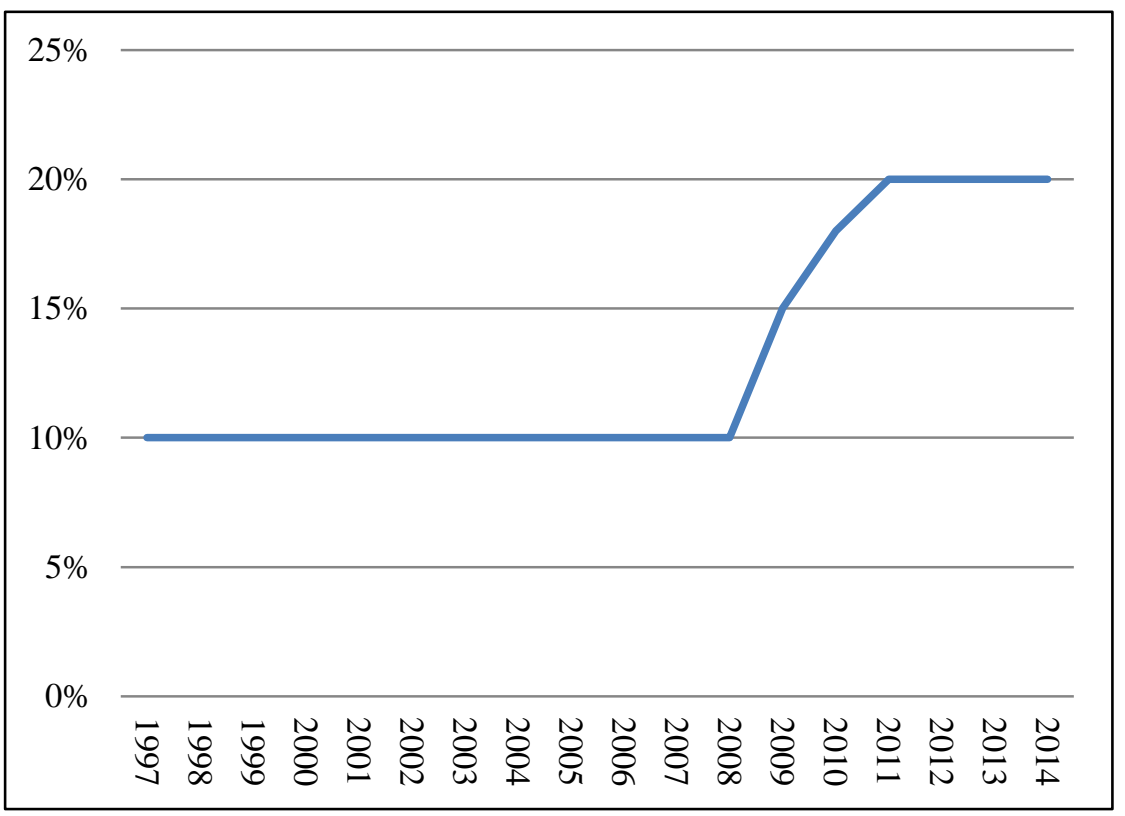

Figure 2. Capital income tax in Iceland

Source: Directorate of Internal Revenue.

\subsection{The development of depreciation allowances rates since 1990}

From 1990-1991, all assets were depreciated by a straight line method with a fixed rate that varied between types of assets. The depreciation base was the original cost price. In 1992, the depreciation rates were made more flexible by implementation of minimum and maximum rates for each depreciation category that were made still wider in 1996, as shown in table 1 :

24 Improving the Equity and Revenue Productivity of the Icelandic Tax System; IMF, June 2010, page 30-33. 


\begin{tabular}{lccc}
\hline & & & \\
Depreciation categories: & 1990 & 1992 & 1996 \\
\hline Passenger cars & $8 \%$ & $6-8 \%$ & $5-10 \%$ \\
Industrial machinery and equipment & $12 \%$ & $9-12 \%$ & $5-15 \%$ \\
Office equipment & $20 \%$ & $15-20 \%$ & $10-20 \%$ \\
Residential buildings, offices and commercial ones & $2 \%$ & $1.5-2 \%$ & $1-3 \%$ \\
\hline \multicolumn{2}{l}{ Source: Directorate of internal revenue. }
\end{tabular}

\section{Table 1. Depreciation categories 1990, 1992 and 1996}

Since 2003, tangible assets such as ships, machinery and aircraft are depreciated by the declining balance method, but buildings, plants, other premises, as well as intangible assets such as copyrights and trademarks are depreciated by the straight line method.

Depreciation categories:

\begin{tabular}{lc}
\hline I. Moveable property (DB) & Since 2003 \\
\hline Passenger cars & $10-20 \%$ \\
Ships and equipment for ships & $10-20 \%$ \\
Aircraft and flight equipment & $10-20 \%$ \\
Industrial machinery and equipment & $10-30 \%$ \\
Office equipment & $20-35 \%$ \\
Other machinery equipment and vehicles & $20-35 \%$ \\
\hline II.Other assets (SL) & \\
\hline Residential buildings, offices and commercial ones & $1-3 \%$ \\
Industrial plants, storage facilities & $3-6 \%$ \\
Quays and greenhouses & $6-8 \%$ \\
Wells, transmission lines, work camps & $7.5-10 \%$ \\
Acquired goodwill & $10-20 \%$ \\
Patents, copyrights and other similar rights & $15-20 \%$ \\
\hline Source: Directoratef
\end{tabular}

Source: Directorate of internal revenue.

Table 2. Depreciation categories since 2003

The depreciation base of movable property is its book value at the beginning of each year, whereas the depreciation base of other depreciable assets is cost price. Residual value of $10 \%$ of the original value of the tangible asset in question remains on account until the asset is scrapped or sold. Accelerated and/or extraordinary depreciation or write-offs are deductible from income in certain limited and specific cases. 


\subsection{The development of the personal income tax rates - self- employed}

The Government policy in the years before the economic collapse in 2008 was to lower the top marginal tax rate on personal wage income. The lowest measure on the top personal income tax was in 2007 and 2008 where the rate was $35.72 \%$. A new tax system with three tax brackets was introduced in 2009 that resulted with similar top marginal tax rate on personal income as in the years before 2002 .

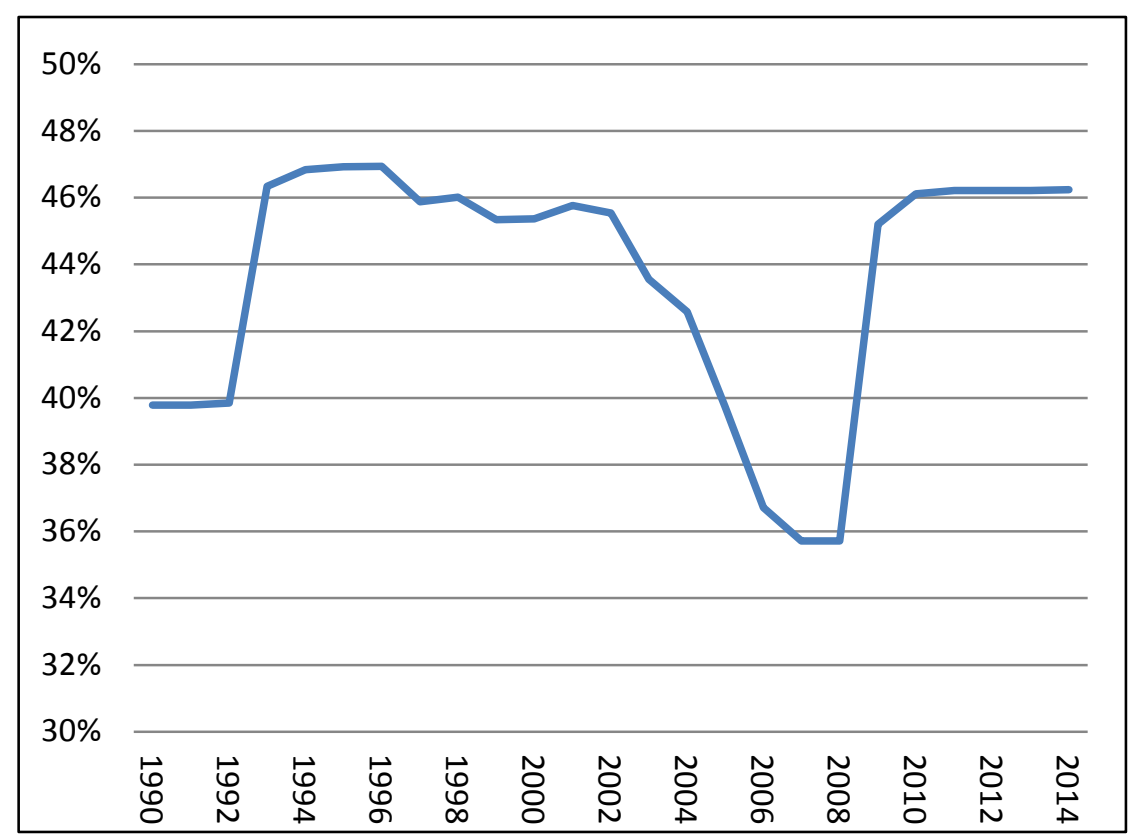

Figure 3. Top marginal tax rate on personal wage income

Source: Directorate of Internal Revenue.

The current system is that of the first ISK 290,000 per month are paid $37.30 \%$ tax, on income from ISK 290,001-784,619 per month are paid $39.74 \%$ tax and income from ISK 784,619 per month are paid $46.24 \%$. Each individual enjoys a personal tax credit, amounting to ISK 50,498 per month, leading to a tax free limit of ISK 135,384 per month.

Special rules are in place for self-employed and owners of closely held companies. They must declare their wages according to rules on minimum imputed wages that are decided and published every year by the Ministry of Finance and Economic Affairs. The imputed wages are then taxed as any personal income. 


\subsection{The development of the corporate level tax rate on wage income (social security contributions)}

In 1991, a two-tier system of social security contributions replaced a very complicated system of various taxes on wages. Up to the end of 1996, this two-tier system of social security contributions was in effect. A lower rate, $3.63 \%$, was levied on agriculture, fisheries, manufacturing, hotels, restaurants, car rentals, the making of motion pictures and computer software services. The higher rate, $6.93 \%$, was levied on all other sectors. The average rate was estimated at 5\%. The two tier system was amended as of the beginning of 1997 with the aim of merging the two rates into one over an adjustment period of four years, 1997-2000.

On January 1, 1997 the first of four steps to harmonise the two-tier system of the social security tax into one became effective. The unified rate of $5.23 \%$ for all industries was fully implemented in the year $2000 .^{25}$ Social security contribution is imposed on all remuneration paid for dependent personal services and presumptive employment income of the self-employed. The contribution is inter alia used to finance the social security system.

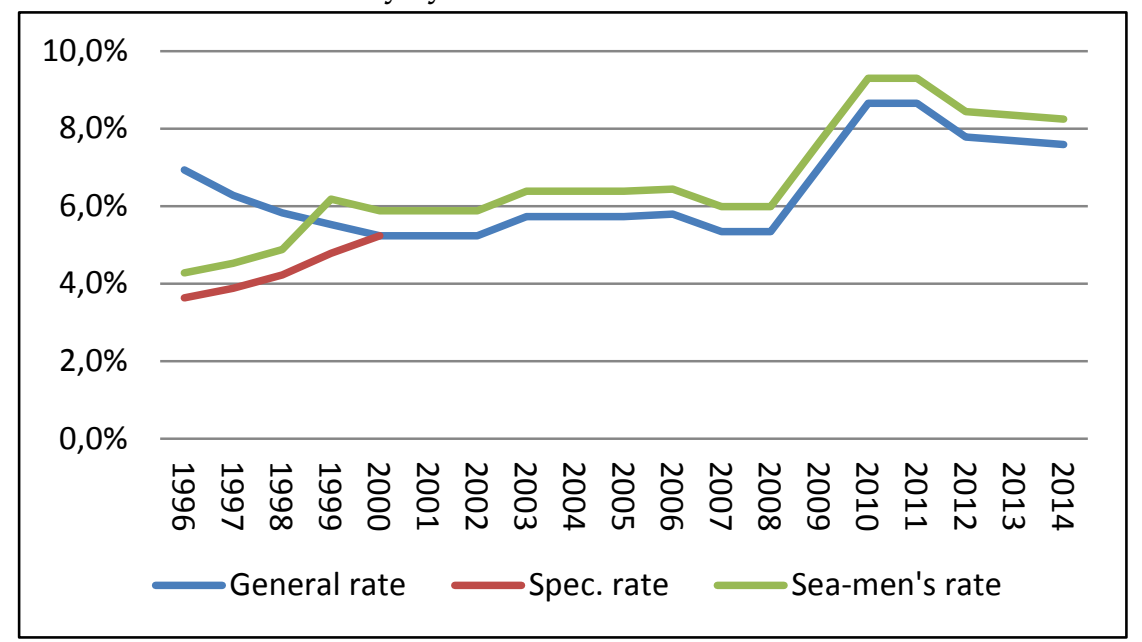

Figure 4. Social security contribution

Source: Directorate of Internal Revenue.

The SSC rate from 1996 to 2014 is shown in figure 4. Included in the SSC rate are other taxes levied on the SSC tax base, but based on other legislation. These taxes are wage guarantee fund and promote Iceland

25 The rate for employers of seamen is slightly higher due to a 0.65 per cent accident insurance premium collected with the tax as of 1 January 2000. 
(Act. 38/2010). The social security contribution was not more than other taxes exempt from the general increase in almost all tax rates after the financial crisis. In the middle of the year 2009 the tax rate was raised from $5.34 \%$ to $7 \%$ and again in 2010 up to $8.65 \%$. Efforts have been made to reduce the SSC rate again and in 2012 it was reduced to $7.78 \%$, in 2013 to $7.69 \%$ and in 2014 to $7.59 \%$.

\subsection{Other changes having effect on companies' taxation}

Some tax changes implemented after the financial crisis having effect on companies' taxation are worth mentioning in this context. One is the $R \& D$ income tax credit, having direct effect on the revenue of the corporate income tax and second the bank tax and the FAT, both levied on the financial sector.

R\&D income tax credit. Since 2010 an income tax credit of 20 per cent has been available for research and development costs. The credit applies to R\&D expenses of at least ISK 1 million (approx. Euro 6,500) annually and that are approved by Icelandic Centre for Research (Rannis), a state agency under the Ministry of Education, Science and Culture. The annual cost ceiling for the credit is ISK 100 million (approx. Euro 6,5 million), or ISK 150 million (approx. Euro 10 million) in case the R\&D services are purchased. If the tax credit exceeds the income tax liability, the unused part is refundable in cash.

Over the period 2010-2012, the R\&D income tax credit has increased from being ISK 485 million to ISK 1,025 million in 2012, and the number of companies making use of it has increased from 188 to 318. Most of the credit is paid out in cash, or $90 \%$ for 2010 (paid out in 2011 ) and $88 \%$ for 2012 . For comparison, the corporate income tax for the income year 2012 amounted to ISK 44,800 million, which means that the R\&D tax credit was around $2.2 \%$ of the total CIT.

Bank tax and FAT. In addition to higher corporate income tax rates, the Icelandic government has implemented new taxes to the financial sector as already discussed in chapter 2.2. One is the bank tax passed by Althingi in 2010 and was effective from $1^{\text {st }}$ of January 2011. The second the financial activity tax (FAT) which entered into force in Iceland on $1^{\text {st }}$ of January 2012. These new taxes were based on the International Monetary Fund's (IMF) recommendations and are in line with taxes on the financial sector that most neighbouring countries have adopted.

The bank tax was first levied on commercial banks, savings banks, credit institutions and other institutions which had an operating license to receive deposits. The tax base is year-end total outstanding debt and the tax rate was $0.041 \%$ until end-year 2013. With amendment in budget 2014 the bank tax was raised to $0.376 \%$ and the tax base widened by abolishing the exemption of financial institutions in win- 
ding-up proceeding and composition negotiation. In order to spare smaller financial institutions the bank tax is levied on year-end total outstanding debt over ISK 50 billion. The expected revenues from the broadening of the bank tax, estimated ISK 23 billion yearly, are intended to finance the government action plan for household debt relief in the years 2014-2017.

As also described in chapter 2.2, the FAT in Iceland has two components:

i. a levy on total remuneration paid to employees at a rate of $5.5 \%$ (decreased in 2014 from $6.75 \%$ previously) and

ii. a special income tax of $6 \%$ on institutions' corporate income tax base in excess of ISK 1 billion.

The decrease in the first component is to counterbalance against the increase in the bank tax. This change will benefit smaller financial institutions, where salary costs are proportionally higher.

When the current FAT scheme was adopted, one of the arguments for the two-fold scheme was that it would target better the value added in the financial industry. However, it has become clear that there is a very large discrepancy between financial institutions' income tax base according to their audited accounts and their income tax base according to the annual tax assessment.

\begin{tabular}{lcccc}
\hline ISK billion & 2012 & 2011 & 2010 & 2009 \\
\hline Audited accounts & 75 & 23 & 87 & 59 \\
Annual tax assessment & 10 & 9 & 25 & 29 \\
Difference & 64 & 14 & 62 & 30 \\
\hline
\end{tabular}

Source: Directorate of Internal Revenue and financial institutions audited accounts.

Table 3. Profits of financial institutions according to audited accounts versus annual tax assessment

Table 3 shows financial institutions audited accounts from 2009 to 2012 together with financial institutions annual tax assessment. The annual tax assessments as a proportion of audited account reached bottom in 2011 and was only 14\% of audited accounts which is the greatest difference thus far. A large discrepancy makes very uncertain revenue from the excess income tax. In the IMF's review of the tax system in June 2010, it was recommended to make the profit determined 
according to the financial statement the basis for the taxable profit ${ }^{26}$. Based on the outcome shown in table 3 in case of the financial institutions, this issue definitely seems to be a weak point in the corporate taxation in Iceland.

\section{The development of corporate tax revenues since 1990}

Figure 5 shows corporate tax revenue, both as a share of total tax revenue and as a share of GDP. In 2002 the corporate tax rate was lowered from $30 \%$ to $18 \%$. This large drop in the corporate tax rate had, however, no major impact on the tax revenues, as the CIT share of total tax revenue went from $4.5 \%$ to $4 \%$ from 2001 to 2002 . In the boom years before the economic collapse in 2008 the corporate tax revenue as a share of total tax revenue ascended substantially, or from $4.2 \%$ in 2004 to $9 \%$ in 2007.

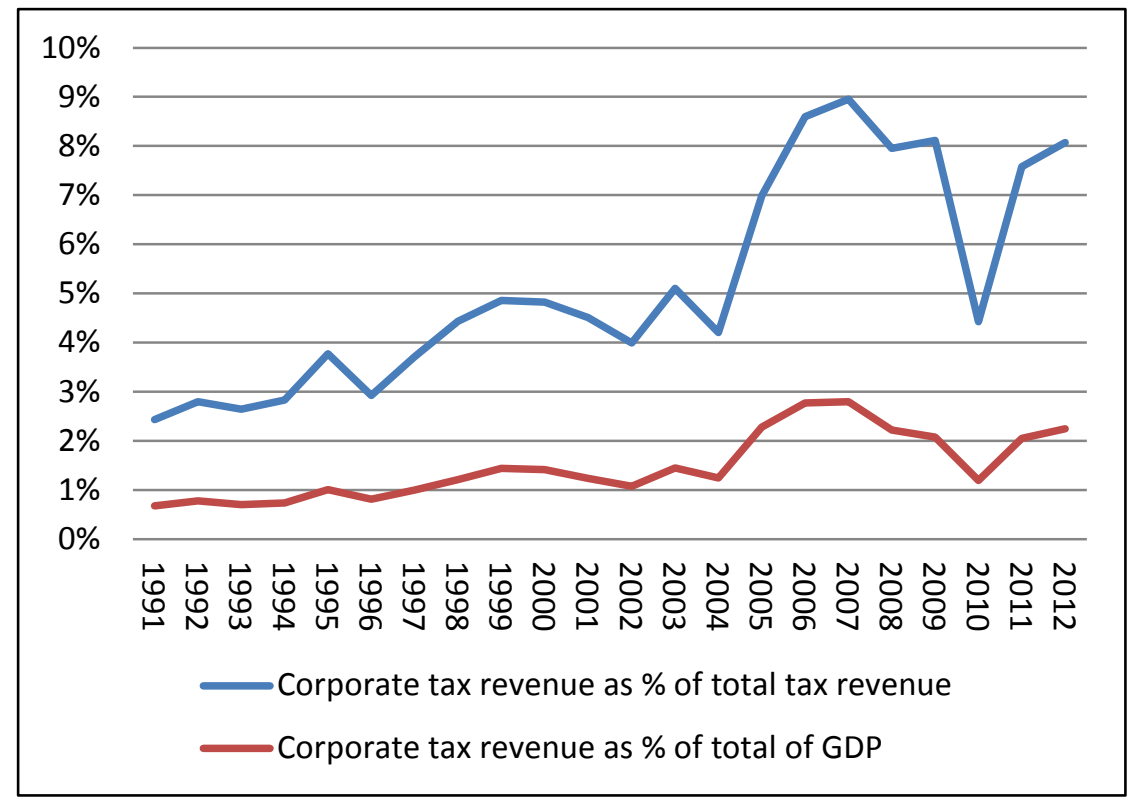

Figure 5. Corporate tax revenue

Source: State Accounting and Statistics Iceland.

The largest part of tax revenue ${ }^{27}$ in the business sector can be traced to financial and real estate sector in 2006 and 2007. In the year 2008 the

26 Improving the Equity and Revenue Productivity of the Icelandic Tax System; IMF, June 2010.

27 Assessed corporate income tax. 
real estate sector collapsed and the share in the tax revenue went from $24 \%$ in 2007 to $4 \%$ in 2008 . The financial sector has kept that position to hold the largest share of tax revenue in the business sector despite a considerable drop from its highest point. The largest increase as a share of tax revenue from 2009 has been in the manufacturing sector, stemming mainly from the fish processing industry.

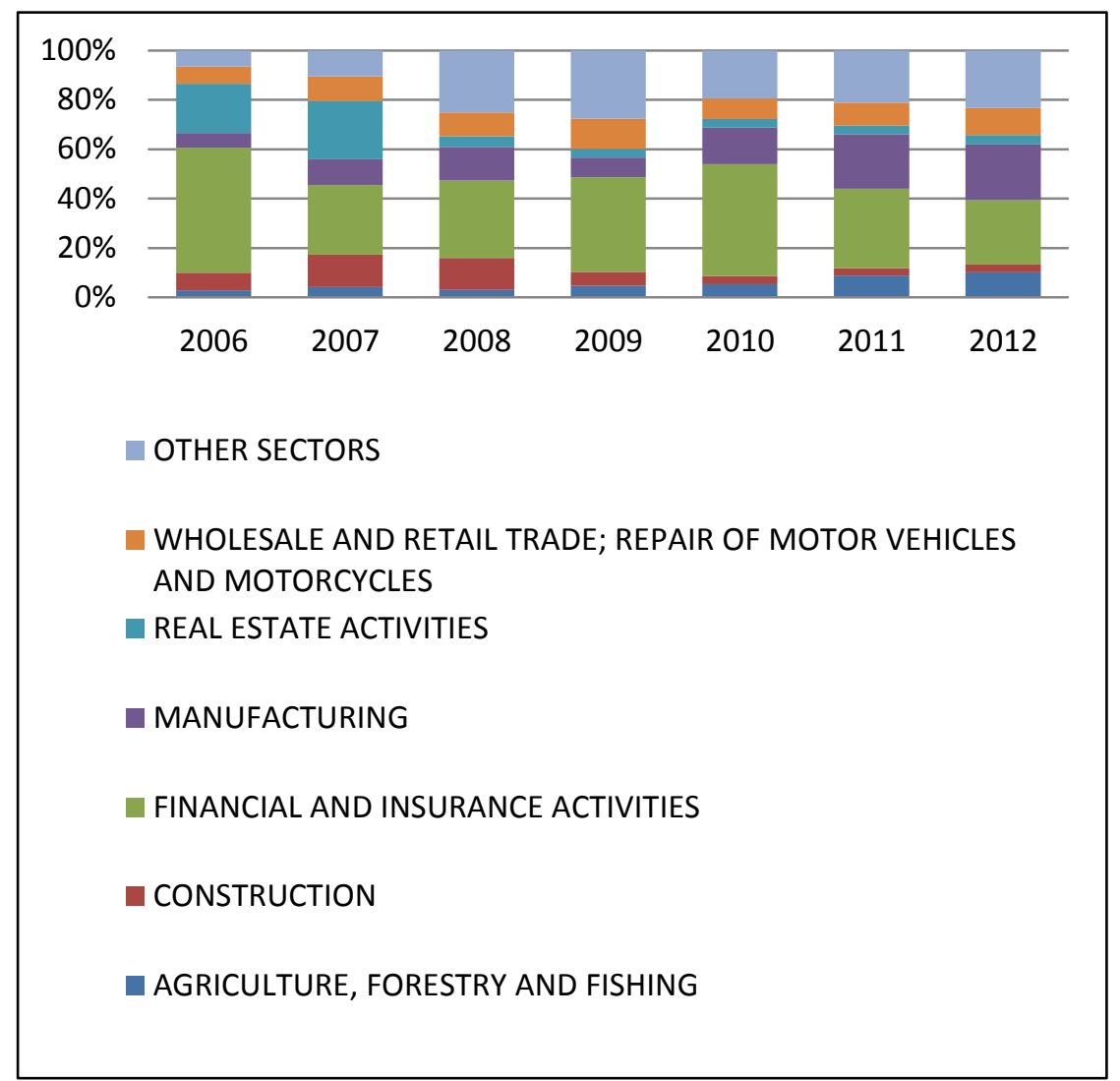

Figure 6. Development of tax revenues in the business sector

Source: Directorate of Internal Revenue.

In the figure 7 the development of the SSC revenue is shown as a share of total tax revenue and as a share of GDP. The SSC revenue share has been on average around $10 \%$ in the period from $1992-2008$. After the rise in SSC in 2009 and 2010 the share rose up to 15\%. After the lowering of SSC rate the SSC revenue as a share of total tax revenue lowered to little less than $14 \%$. On average the SSC revenue as a share of GDP have been around 2.8\% from 1992 to 2008. The share went up to $4.1 \%$ for the years 2010 and 2011. Parallel the reduction in the SSC rate the share of GPD has decreased as well.

168 Fjóla Agnarsdóttir \& Rakel Jensdóttir 


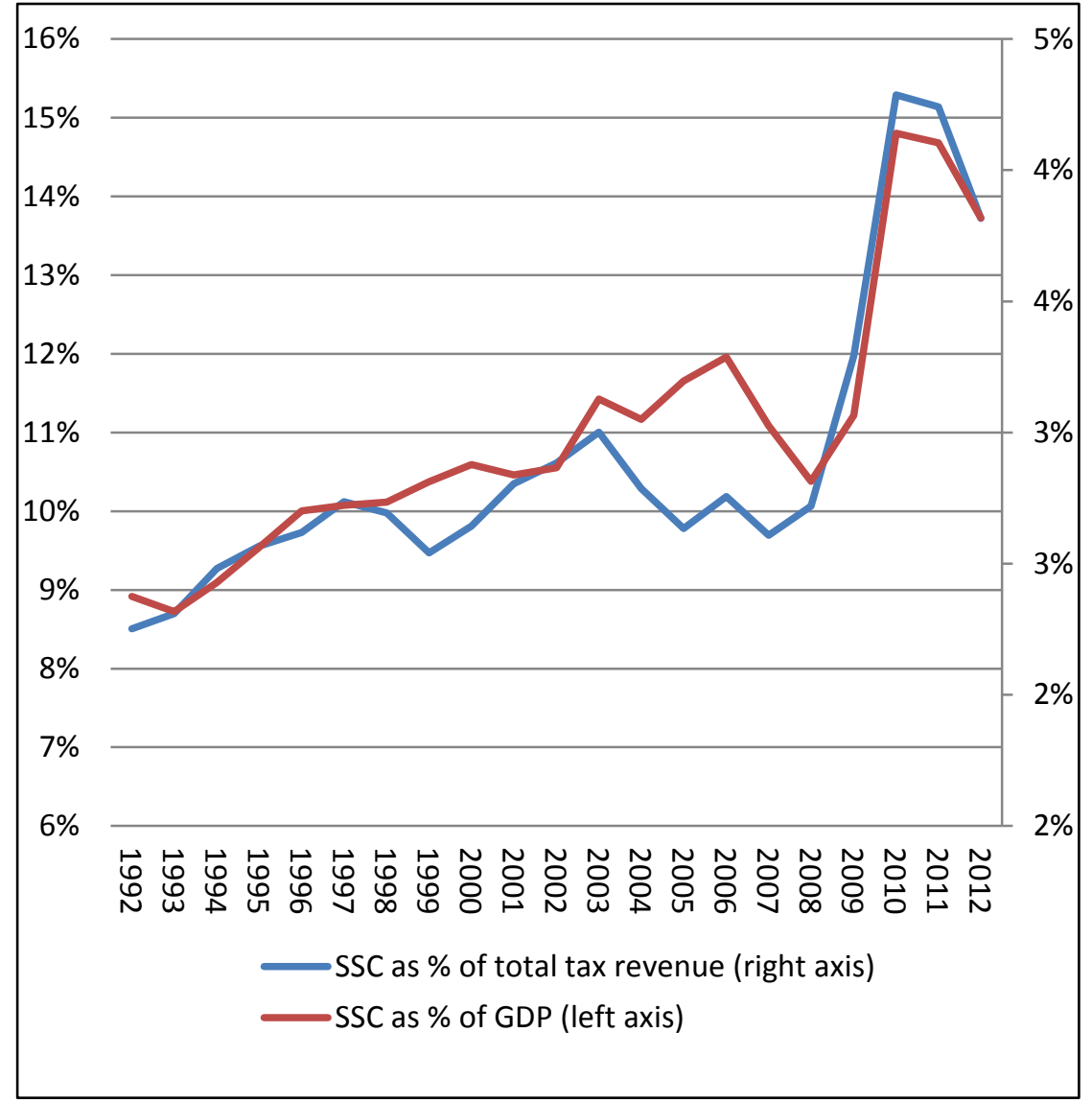

Figure 7. SSC revenue

Source: State Accounting.

6. The development of real investments since 1990

Historically, real investment in Iceland is very low and has been from 2008 when the country's banking system collapsed. In business sector major driving force has been in heavy industry and electricity power plant, especially from 2002 to 2006. 


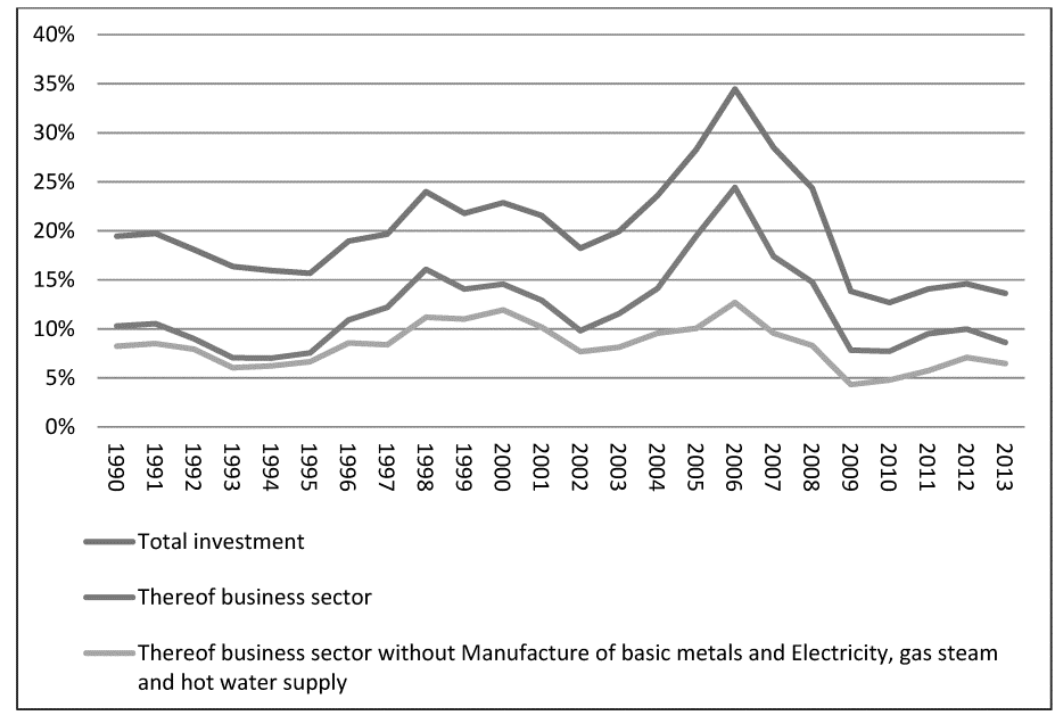

Figure 8. Gross fixed capital formation, \% of GDP

Source: Statistics Iceland.

Until 2005 foreign investment in Iceland has been rather small on international standards. Favourable electricity prices have attracted foreign investment in energy intensive industries, particularly aluminium companies. Figure 9 shows foreign direct investment in Iceland from 1990 until 2012. Foreign direct investment is divided into two components, equity and inter-company loans. Since 2005 foreign direct investment escalated into new heights. A large rise in intercompany loans in 2008 can partly be traced to the fact that the national currency lost over half of its value. It is interesting to view intercompany loans in connection with transfer pricing. There has not yet been conducted a theoretical study of inter-company loans in connection with transfer pricing. However the Directorate of Internal Revenue is at the moment doing a research on transfer pricing on aluminium companies with foreign ownership operating in Iceland. 


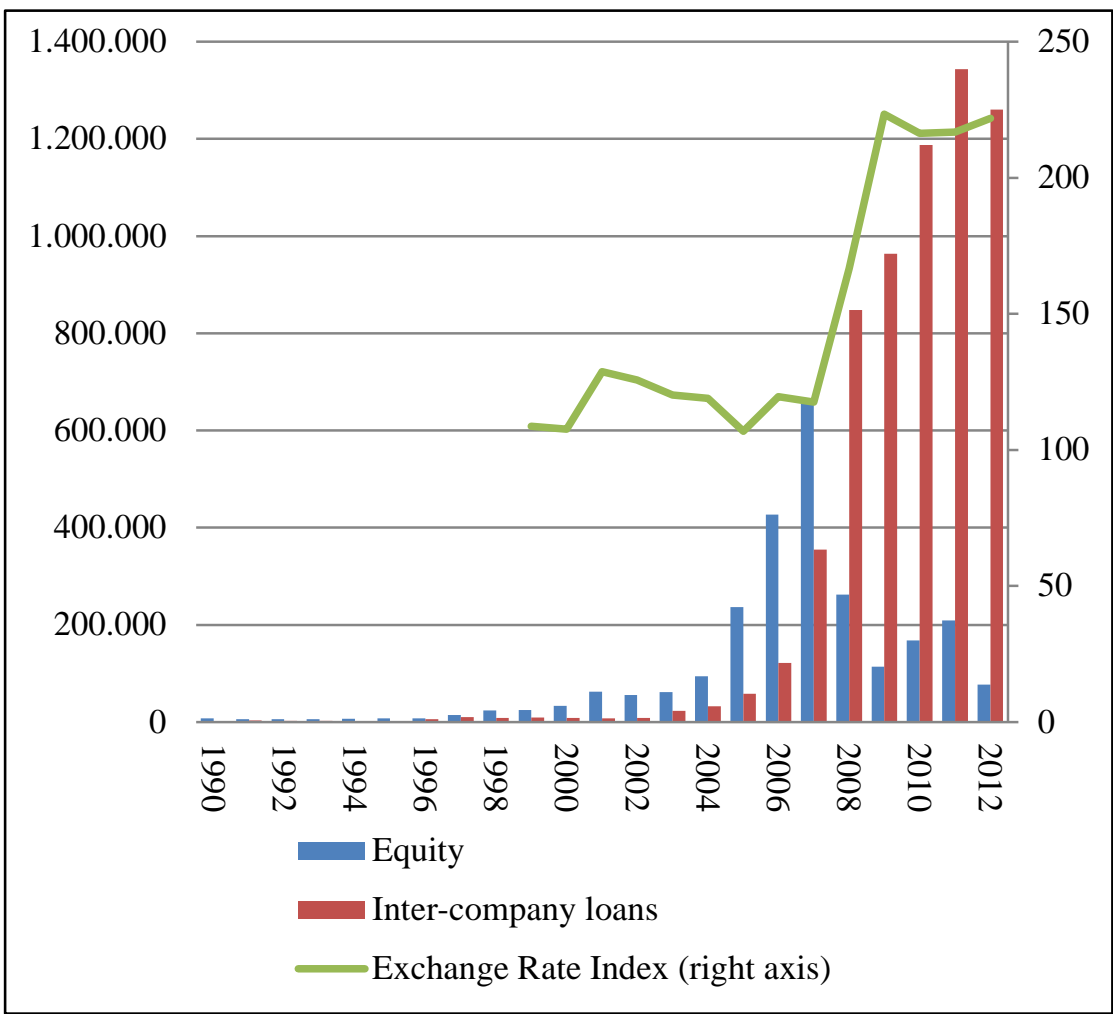

Figure 9. Foreign direct investment, m.kr.

Source: The Central Bank of Iceland.

\section{Conclusion}

There have been rapid changes in the field of corporate taxation in Iceland for the past few years both because of the economic situation and increased need for tax avoidance measures. The capital controls have, as well, enormous effect on the corporate environment both for domestic and foreign companies. Following are the main conclusions that can be drawn from this article on the Icelandic corporate taxation and the international challenges ahead.

- New taxes have been introduced for certain economic sectors, especially the financial sector, and tax rates have been raised.

- Loopholes for tax avoidance have been narrowed with the clarification and introduction of new anti-avoidance measures and a strengthened network of agreements on exchange of information. 
- The Tax Authorities should consider seriously the recommendation from IMF regarding the financial statement according to their audited accounts as a basis for the taxable profit.

- The lack of capital mobility in Iceland has a major impact on the investment climate in Iceland.

- Presently, the capital controls have most likely more impact on foreign investment in Iceland than the tax conditions.

- Due to the capital controls the Icelandic economy is rather closed and therefore issues relating to base erosion and profit shifting are of less relevance at the moment.

- $\quad$ Some criticism has been voiced in the past few years concerning the PE definition of the Icelandic income tax legislation which is in accordance with the OECD standards. The PE of servers is the main problem.

- Competitive prices of the green energy sector is the main attraction for locating servers of multinational companies in Iceland.

- $\quad$ Thus, the emergence of the borderless digital economy is already challenging the Icelandic tax system.

- It will be a great challenge for the Icelandic tax authorities in the future to tackle that issue, especially as regards tax treaties.

In short, the policy of the present Government in Iceland is to move the tax burden away from income tax, i.e. the corporate income tax towards tax bases that are less harmful to growth, like consumption, with the aim to make the tax system simpler and more effective, both from economic and competitive point of view. 